\title{
Climate change and thresholds of biome shifts in Amazonia
}

\author{
Luis Fernando Salazar ${ }^{1,2}$ and Carlos A. Nobre ${ }^{1}$ \\ Received 6 April 2010; revised 14 July 2010; accepted 26 July 2010; published 11 September 2010.
}

[1] We examine potential critical thresholds for biome shift in the Amazonian tropical forest by forcing a potential vegetation model with prescribed climate anomalies and projections from global and regional climate models and different levels of $\mathrm{CO}_{2}$ fertilization effect under the SRES A2 scenario (2070-2099). The results indicate that tropical forests might be replaced by seasonal forests or savanna over eastern Amazonia with temperature increases of $2-3^{\circ} \mathrm{C}$ $\left(4-5^{\circ} \mathrm{C}\right)$, when $\mathrm{CO}_{2}$ fertilization effect is not considered (partially considered), depending on precipitation anomaly. A precipitation decrease greater than $30 \%$ would trigger the shift from tropical forest to drier biomes, such as savanna and shrubland in southeastern Amazonia. The projected decrease in precipitation during the dry season and the increase of temperature are the main mechanisms driving calculated biome changes. However, biome changes are considerably smaller when the optimum fertilization effect is included. Citation: Salazar, L. F., and C. A. Nobre (2010), Climate change and thresholds of biome shifts in Amazonia, Geophys. Res. Lett., 37, L17706, doi:10.1029/2010GL043538.

\section{Introduction}

[2] The Amazon forest plays an essential role in the global atmospheric circulation [Malhi et al., 2008] and the southward atmospheric moisture flow out of the region may represent a significant moisture source for precipitation in some areas in South America [Marengo et al., 2004; Nobre et al., 1991]. In recent decades, the warming rate in Amazonia has been about $0.25^{\circ} \mathrm{C} /$ decade [Victoria et al., 1998; Malhi and Wright, 2004] and the climate change projections indicate a mean increase of $3.3^{\circ} \mathrm{C}$ under an intermediate emissions scenario for the end of 21st century [Salazar et al., 2007; Nobre and Borma, 2009]. Precipitation projections, though without consensus in relation to the sign of the annual anomaly [ $\mathrm{Li}$ et al., 2006], indicate precipitation decrease in the dry season. This is the most critical factor for the forest sustainability in the future [Salazar et al., 2007; Malhi et al., 2008; Nobre and Borma, 2009]. These changes might impact not only biological and socio-economical aspects, but also amplify the global climate change due to respiration increase and reduced carbon uptake [Cox et al., 2004]. Over the Amazon forest, a drier and warmer climate (due to climate change, land use changes, or combined effects) would allow an equilibrium climate condition with vegetation more resistant (e.g., savannas) to the multiple stresses caused by high temperatures, droughts, and fire

\footnotetext{
${ }^{1}$ Center for Earth System Science, National Institute of Space Research, Cachoeira Paulista, Brazil.

${ }^{2}$ Escuela de Ingeniería Civil, Universidad Industrial de Santander, Bucaramanga, Colombia.

Copyright 2010 by the American Geophysical Union. 0094-8276/10/2010GL043538
}

increase [Nobre et al., 1991; Salazar et al., 2007; Nobre and Borma, 2009].

[3] Some studies [e.g., Cox et al., 2004; Scholze et al., 2006; Cook and Vizy, 2008; Salazar et al., 2007], based on different models and under different emission scenarios, project a total or partial reduction in the tropical Amazon forest by the end of the 21 st century. Other studies do not show significant changes in vegetation [e.g., Cramer et al., 2001; Alo and Wang, 2008; Sitch et al., 2008] or show a shift of tropical forest to seasonal forest [e.g., Lapola et al., 2009; Malhi et al., 2009] under certain climate change scenarios.

[4] Oyama and Nobre [2003] show that the eastern Amazon could have two equilibrium vegetation-climate states. The difference between them would depend directly on atmospheric forcing or indirectly, on changes on land use. Lenton et al. [2008] and Kriegler et al. [2009] analyze critical thresholds of some elements in the climate system. The study shows a critical threshold with a temperature increase of $3-4^{\circ} \mathrm{C}$ in Amazonia. A key point for the consequences of climate change in biome distribution is the effect of higher atmospheric $\mathrm{CO}_{2}$ in carbon uptake through the $\mathrm{CO}_{2}$ fertilization effect [Curtis and Wang, 1998; Prentice et al., 2001; Lapola et al., 2009]. The magnitude of the fertilization effect has been validated with field experiments in temperate ecosystems [Norby et al., 2005], but the impact on tropical forest has remained uncertain. In this study we go further on this type of analysis by consideration of the simultaneous effects of temperature increase and precipitation changes brought about by different global warming scenarios, and different levels of $\mathrm{CO}_{2}$ fertilization effect (under A2 SRES scenario) using a regional potential vegetation model to evaluate critical thresholds to biome shift in Amazonia.

\section{Material and Methods}

[5] The potential vegetation model used is the CPTECPVM2.0Reg [Salazar, 2009], a regional version of CPTECPVM2.0 [Lapola et al., 2009]. The CPTEC-PVM2.0Reg considers seasonality as a determinant factor for the delimitation of forests and savannas. It also takes into account physiological responses of vegetation to seasonality (such as primary productivity) under variable atmospheric $\mathrm{CO}_{2}$. The biome allocation relies mainly on the optimum net primary productivity (NPP) values for a given grid cell. The determination of biome distribution through NPP is based on numerous studies showing that different biomes have typically different average NPP [e.g., Turner et al., 2006]. However, NPP can be quite similar among biomes in some cases, and hence variables other than NPP are used for biome allocation. As a non-dynamic model, the CPTECPVM2.0Reg calculates only equilibrium solutions based on long-term mean monthly climate variables. This is done 

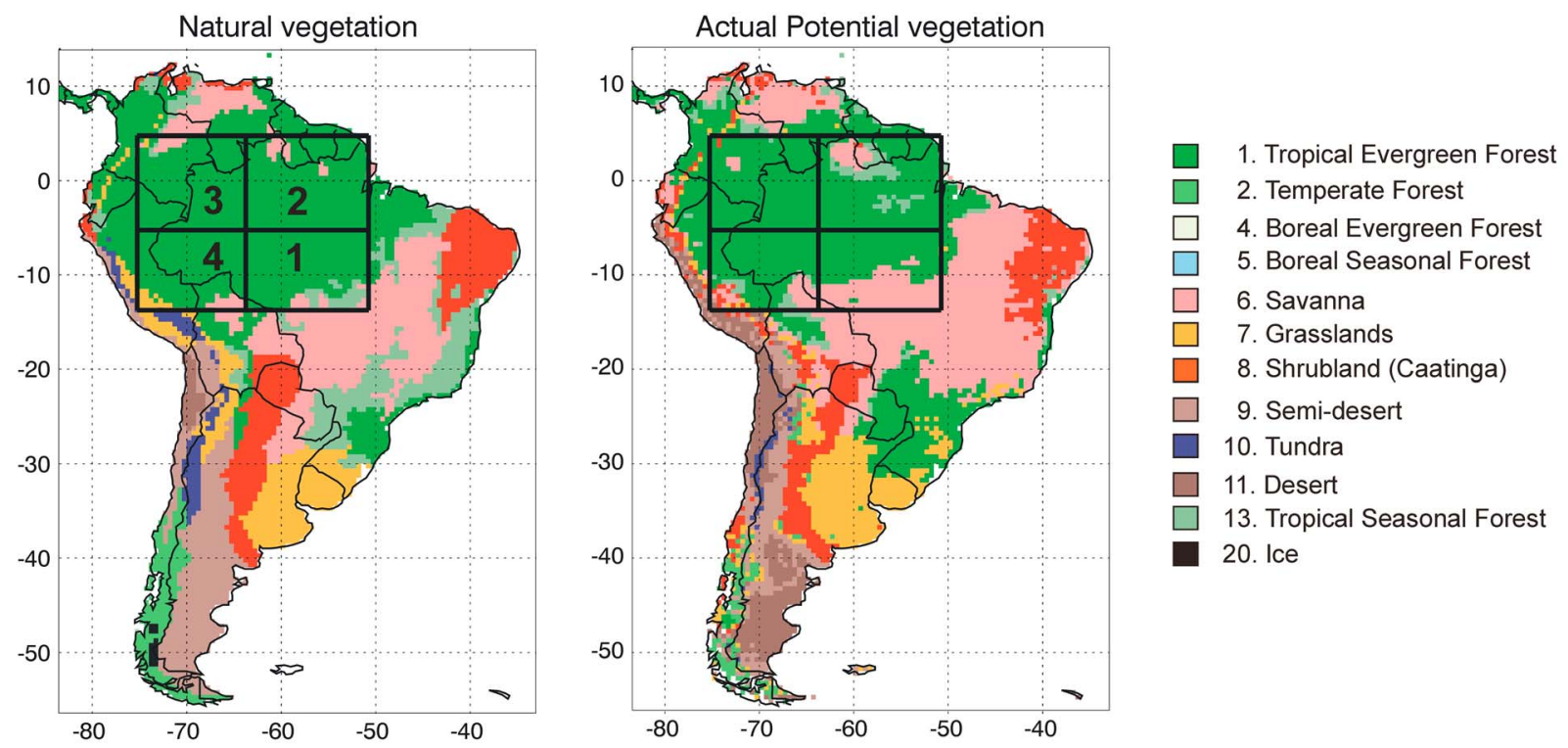

Figure 1. Natural vegetation reference map [Salazar, 2009] and actual potential vegetation simulated by CPTECPVM2.0Reg model under the 1961-1990 mean climate. The division of the Amazon domain is indicated by the continuous box in the natural vegetation map. Region 1: Southeast $\left(5.25^{\circ} \mathrm{S}-13.75^{\circ} \mathrm{S} ; 50.75^{\circ} \mathrm{W}-63.75^{\circ} \mathrm{W}\right)$; Region 2: Northeast $\left(4.75^{\circ}\right.$ $\left.\mathrm{N}-5.25^{\circ} \mathrm{S} ; 50.75^{\circ} \mathrm{W}-63.75^{\circ} \mathrm{W}\right)$; Region 3: Northwest $\left(4.75^{\circ} \mathrm{N}-5.25^{\circ} \mathrm{S} ; 63.75^{\circ} \mathrm{W} ; 75.25^{\circ} \mathrm{W}\right)$; Region 4: Southwest $\left(5.25^{\circ} \mathrm{S}-\right.$ $\left.13.75^{\circ} \mathrm{S} ; 63.75^{\circ} \mathrm{W}-75.25^{\circ} \mathrm{W}\right)$.

concomitantly by a water balance sub-model using climatological values of surface temperature and precipitation (1961-1990 (C. J. Willmott and K. Matsuura, Terrestrial air temperature and precipitation: Monthly and annual climatologies, University of Delaware, Newark, 1998, http:// climate.geog.udel.edu/ climate/html_pages/archive.html)), intercepted photosynthetically active radiation $\left(\mathrm{I}_{\mathrm{PAR}}\right)(1986-$ 1995 [Raschke et al., 2006]), soil classes [Food and Agriculture Organization of the United Nations, 1991], and atmospheric $\mathrm{CO}_{2}$ concentration [IPCC, 2007] as inputs.

[6] In order to evaluate biome shift thresholds in Amazonia, the CPTEC-PVM2.0Reg is integrated with different prescribed precipitation $(-50,-40,-30,-20,-100,10,20$, 30,40 e $50 \%$ ) and temperature $\left(0,1,2,3,4,5,6\right.$ e $\left.7^{\circ} \mathrm{C}\right)$ annual anomalies, added to the observed climatology. Furthermore, different levels of $\mathrm{CO}_{2}$ fertilization effect (fully considered: $100 \%$; partially considered: $25 \%$; and nonexistent: $0 \%$ ) under emissions scenario A2 (mean atmospheric $\mathrm{CO}_{2}$ concentration of $730 \mathrm{ppmv}$ ) are used for the period 2070-2099. We include the fertilization effect in the model scaling the increase in $\mathrm{CO} 2$ concentration from 1960-1990 level (350 ppmv) to 2070-2099 projected level (730 ppmv, in A2 scenario) with the percentages analyzed $(0 \%, 25 \%$ and $100 \%)$. To compare the biome in equilibrium with model projections, we use annual climate anomalies projected from global and regional model scenarios. The regional scenarios taken from regional climate models (RCM) for South America (50 km resolution), integrated in the CREAS project [Marengo, 2009; Marengo and Ambrizzi, 2006], are: ETA CCS, RegCM3 and HadRM3P. The global scenarios use standard output, available through the World Climate Research Programme's (WCRP's) Coupled Model Intercomparison Project phase 3 (CMIP3) multimodel dataset, from fifteen Coupled Ocean-Atmosphere GCMs for the IPCC AR4: BCCR-BCM2.0, CCSM3, CGCM3.1(T47), CNRM-CM3, CSIRO-Mk3.0, ECHAM5/MPI-OM, ECHO-
G, GFDL-CM2.0, GFDL-CM2.1, GISS-ER, INM-CM3.0, IPSL-CM4, MIROC3.2(MedRes), MRI-CGCM2.3.2, and UKMO-HadCM3. The anomalies for global and regional models are calculated as the difference between the present climate (1961-1990) and the future scenario A2 (20712100) simulated by each model (this methodology filters out the effect of GCM's systematic errors). We divide the Amazon basin into four quadrants (see Figure 1) due to differences in climate seasonality and climate change projections [Vera et al., 2006]. For each region, we calculate the dominant biome (the highest occupation area in the region) using all combinations of prescribed climate anomalies and $\mathrm{CO}_{2}$ fertilization effect. Superimposed to Figure 1, we calculated the dominant biome in equilibrium with climate change projections from the regional models, selected global models (GISS-ER, ECHAM5 and HadCM3) and the mean of the fifteen global models. These three global models are selected based on their capacity to simulate current climate in South America [Covey et al., 2003; Li et al., 2006] and also to capture in the analysis the range of somewhat divergent projections (mainly in precipitation).

\section{Results}

[7] Figure 1 shows the natural vegetation reference map [Salazar, 2009] and the biome distribution simulated by the CPTEC-PVM2.0Reg model under current climate. To measure the degree of similarity between the natural and potential maps, the kappa $(\kappa)$ statistics [Monserud and Leemans, 1992] is used. For South America, the $\kappa$ average value is 0.48 (comparable to other models like BIOME), which is considered an acceptable value. For tropical biomes, the agreement is good for tropical forest $(\kappa=0.66)$ and shrubland $(\kappa=0.57)$; acceptable for savannas $(\kappa=0.51)$ and grasslands $(\kappa=0.49)$; and poor for seasonal tropical forests $(\kappa=0.03)$. 
Fertilization effect: $0 \%$
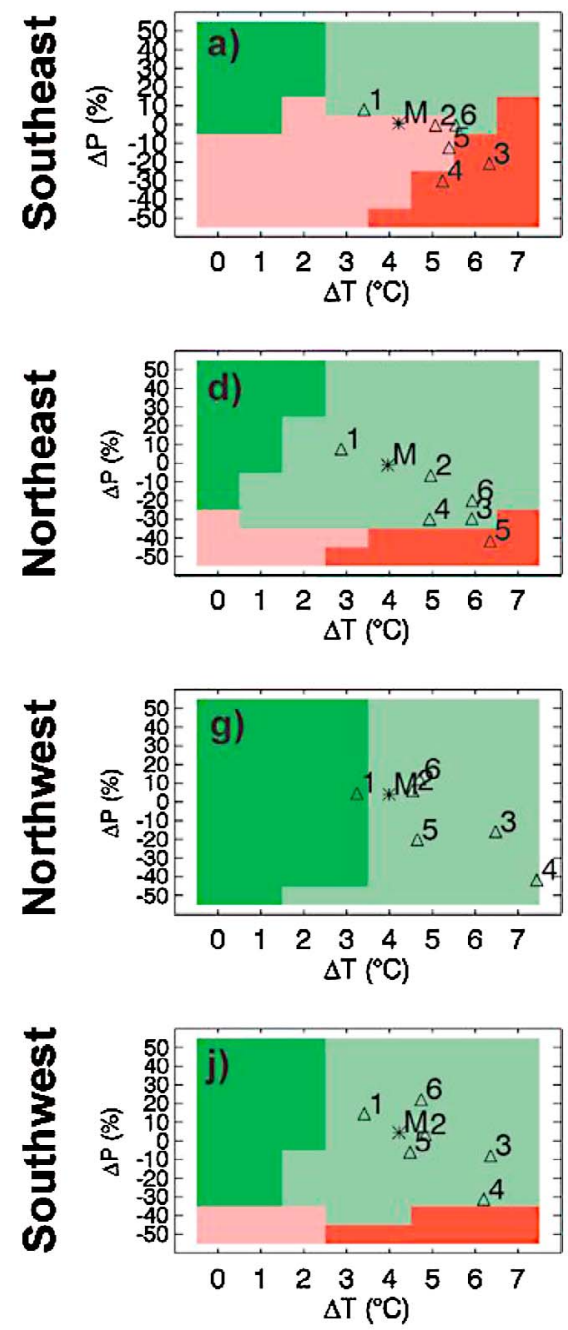

Tropical Forest Savanna
Fertilization effect: $\mathbf{2 5 \%}$
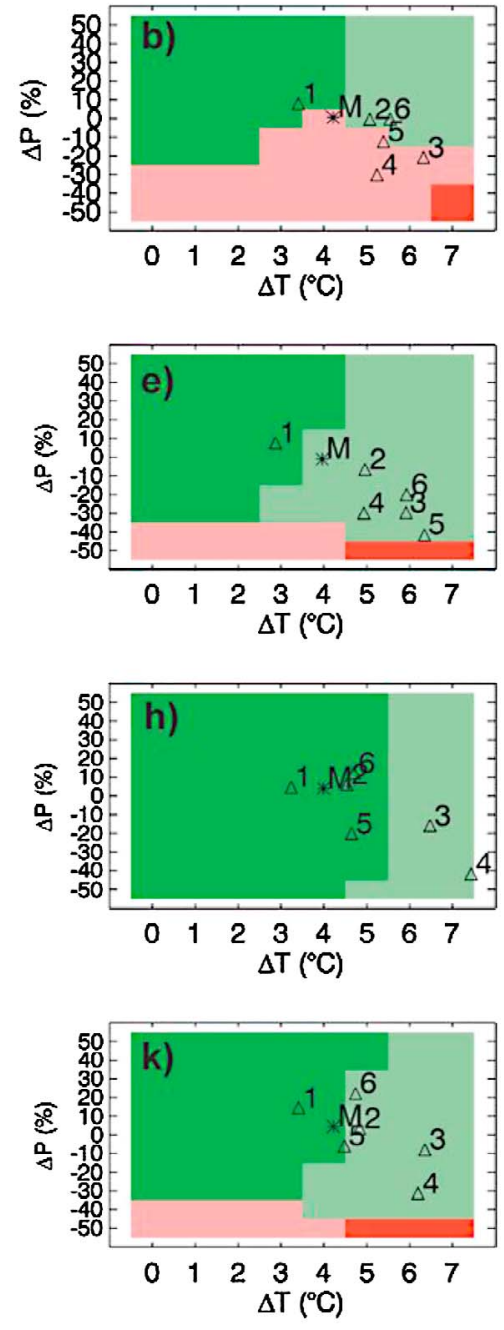

Shrubland

Seasonal Forest

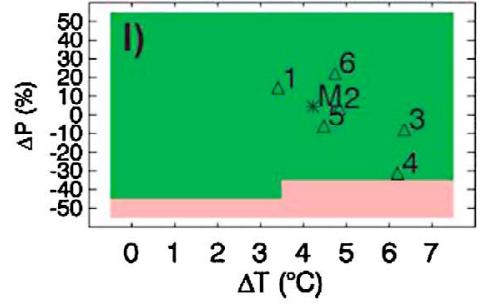

Fertilization effect: $\mathbf{1 0 0 \%}$
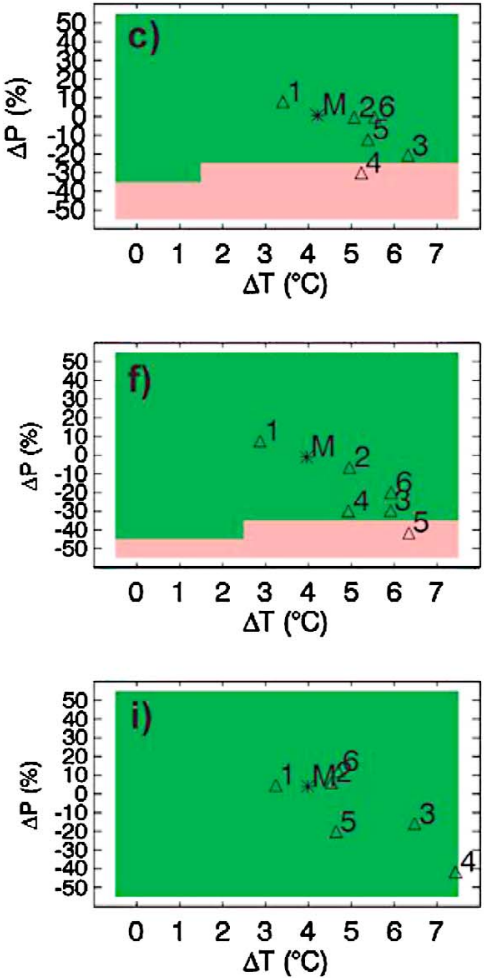

4: ETA CCS

5: $\operatorname{Reg} \mathrm{CM} 3$

6: HadRM3P
1: GISS-ER

2: ECHAM5

3: $\mathrm{HadCM} 3$

M: IPCC mean

Figure 2. Potential dominant biome simulated by CPTEC-PVM2.0Reg for different temperature anomalies, precipitation changes, and fertilization effects $(0 \%, 25 \%$ and 100\%) for SRES A2 climate scenario for the period 2070-2099, and for the regions of Amazonia (indicated in Figure 1): $(\mathrm{a}-\mathrm{c})$ southeast, $(\mathrm{d}-\mathrm{f})$ northeast, $(\mathrm{g}-\mathrm{i})$ northwest and $(\mathrm{j}-\mathrm{l})$ southwest Amazonia. The climate anomalies projected by regional (ETA CCS, RegCM3 and HadRM3P) and selected global (GISS-ER, ECHAM5, HadCM3 and M: average of fifteen global models from IPCC) models are plotted for each region.

[8] Figure 2 shows the dominant biome in each region when the PVM model is integrated with prescribed climate and fertilization effects. In eastern Amazonia, if the fertilization effect is non-existent (Figures $2 \mathrm{a}$ and $2 \mathrm{~d}$ ), there is a shift to savanna when the annual precipitation decrease is greater than $10 \%$ or to seasonal forest when the temperature increase is greater than $2^{\circ} \mathrm{C}$. In extreme temperature and precipitation anomalies (as projected by HadCM3 and ETA CCS models), the model simulates a dominance of shrubland (caatinga) biome. When the $\mathrm{CO}_{2}$ fertilization effect is considered at 25\% efficiency (Figures $2 \mathrm{~b}$ and $2 \mathrm{e}$ ), the shift to seasonal forest (savanna) occurs when the temperature is greater than $4^{\circ} \mathrm{C}$ (precipitation decrease is greater than
$30 \%$ ). In this simulation, a large increase in temperature alone $\left(>4^{\circ} \mathrm{C}\right)$ is sufficient to drive the biome shift through reduced NPP, but not the seasonality (shifting the biome to tropical seasonal forest). In the case of full (100\%) fertilization effect (Figures 2c and 2f), the temperature increase does not affect the tropical forest biome (due to the optimal water use by plants in conditions of higher $\mathrm{CO}_{2}$ concentrations and full fertilization effect), maintaining a critical threshold of $40 \%$ in precipitation decrease to replace tropical forest with savanna (due to increase in the dry season length).

[9] Northeast and southwest Amazonia show similar thresholds for biome shift. In all simulations, a precipitation 
decrease $>40 \%$ changes the tropical forest into savanna or shrubland (depending on temperature increase). The critical threshold to replace tropical forest with seasonal forest is $2^{\circ} \mathrm{C}$ when the fertilization effect is non-existent or $4^{\circ} \mathrm{C}$ when fertilization effect is partially considered. Northwest Amazonia does not show a biome change to savanna (Figures $2 \mathrm{~g}-2 \mathrm{i}$ ) and the critical threshold for biome shift to seasonal forest occurs when temperature increase is $>3^{\circ} \mathrm{C}\left(>5^{\circ} \mathrm{C}\right)$ and the fertilization effect is non-existent (partially considered). In the case of maximum fertilization effect, there is no biome change even under conditions of precipitation decrease.

[10] The projections of GCMs and RCMs in the Amazon region show that there are no changes in dominant biome when maximum fertilization effect is considered (Figures 2c, 2f, 2i, and 2l) (except in ETA/CCS for Southeast and RegCM3 for Northeast). When the fertilization effect is nonexistent, the models show a shift to seasonal forest in northeast (Figure 2d), northwest (Figure 2g), and southwest (Figure 2j) regions (except for RegCM3 in Northeast and GISS-ER in Northwest). For the southeast region (Figure 2a), GISS-ER and HadRM3P project a biome shift to seasonal forest; ECHAM5, RegCM3 and average IPCC models to savanna, and HadCM3 and ETA CCS, to shrubland. When the fertilization effect is partially considered (25\%), the HadCM3 and ETA/CCS show a biome shift to savanna in the southeastern region and to seasonal forest in the other areas. GISS-ER maintains a tropical forest in all areas while the average of IPCC models shows a biome shift to savanna in the southeast, to seasonal forest in northeast; and no changes in western regions.

[11] In these calculations, biome changes in Amazonia are related to climate anomalies and fertilization effect considerations. The increase in temperature alone would be enough to change the biome through reduced NPP (the critical threshold depends on the $\mathrm{CO} 2$ fertilization effect considered). The decrease of precipitation and increase of dry season length would trigger the shift from tropical forest (evergreen or seasonal) to drier biomes as savannas and caatinga [Lapola et al., 2009], depending on temperature anomaly and level of fertilization effect (except for northwest Amazonia, where the decrease of $50 \%$ in precipitation is not sufficient to significantly increase the dry season length).

\section{Conclusions}

[12] The future of the tropical forest under different climate change scenarios is still an open question. The uncertainties come from divergences in climate projections and current knowledge of tropical forest response to elevated $\mathrm{CO}_{2}$ concentrations (fertilization effect) and adaptation mechanisms. Furthermore, climate biophysical feedbacks from climateinduced changes in land cover could modify the future vegetation distribution. Therefore, improved understanding on how the complex tropical ecosystems are and will be responding to the atmospheric $\mathrm{CO}_{2}$ increase is a key question to reduce uncertainties in the projections of future biome changes in Amazonia. Our results indicate that different levels of fertilization effect show different critical thresholds to biome shift.

[13] Precipitation decreases of $30 \%$ in the southeast and $40 \%$ in the northeast and southwest represent an increase of the dry season length to more than 4 months and shifts to savanna vegetation. In agreement with Lapola et al. [2009], we find that this threshold is critical to maintain tropical forests, even in conditions of maximum fertilization effect.

[14] There is a clear dependence between the temperature threshold and the magnitude assumption of the fertilization effect. In the case of no $\mathrm{CO}_{2}$ fertilization, the critical threshold for biome shift in Amazonia is $2-3^{\circ} \mathrm{C}$ up to $4-5^{\circ} \mathrm{C}$ when the fertilization effect is partially considered (25\%). The biome that would replace the original vegetation type depends on the precipitation changes.

[15] Our simulations show that eastern Amazonia is the most vulnerable region for biome changes. In conditions of partial fertilization effect, the GCMs and RCMs projections indicate biome shifts into seasonal forest or savanna (except for the GISS-ER model because of its projected increase in precipitation). If the local deforestation effect on eastern and southeastern Amazonian climate [Sampaio et al., 2007] is combined with climate change scenarios, the tropical forest degradation might be accelerated [Nepstad et al., 2008; Malhi et al., 2009; Nobre and Borma, 2009]. Furthermore, some studies point out [Malhi et al., 2009; Nobre and Borma, 2009] that an environment of increasing anthropogenic fire activity (ignition points due to forest deforestation, fragmentation and logging) exacerbated by a drier and warmer climate [Hutyra et al., 2005; Cardoso et al., 2003] might accelerate the biome shift from seasonal forest to savanna.

[16] Acknowledgments. This paper is part of the first author's Ph.D. thesis, under the guidance of the second author, with a scholarship from the Coordenação de Aperfeiçoamento de Pessoal de Nível Superior (CAPES). We are grateful to W. Knorr and two anonymous reviewers for useful comments and suggestions on the manuscript. We thank the modeling groups for making their simulations available for analysis, the Program for Climate Model Diagnosis and Intercomparison (PCMDI) for collecting and archiving the CMIP3 model output, and the WCRP's Working Group on Coupled Modeling (WGCM) for organizing the model data analysis activity.

\section{References}

Alo, C. A., and G. Wang (2008), Potential future changes of the terrestrial ecosystem based on climate projections by eight general circulation models, J. Geophys. Res., 113, G01004, doi:10.1029/2007JG000528.

Cardoso, M. F., G. C. Hurtt, B. Moore, C. A. Nobre, and E. M. Prins (2003), Projecting future fire activity in Amazonia, Global Change Biol., 9, 656-669, doi:10.1046/j.1365-2486.2003.00607.x.

Cook, K. H., and E. K. Vizy (2008), Effects of twenty-first-century climate change on the Amazon rainforest, J. Clim., 21, 542-560, doi:10.1175/ 2007JCLI1838.1.

Covey, C., K. M. Achutarao, U. Cubasch, P. Jones, S. J. Lambert, M. E. Mann, T. J. Phillips, and K. E. Taylor (2003), An overview of results from the Coupled Model Intercomparison Project, Global Planet. Change, 37(1-2), 103-133, doi:10.1016/S0921-8181(02)00193-5.

Cox, P. M., R. A. Betts, M. Collins, P. P. Harris, C. Huntingford, and C. D. Jones (2004), Amazonian forest dieback under climate-carbon cycle projections for the 21st century, Theor. Appl. Climatol., 78, 137-156, doi:10.1007/s00704-004-0049-4.

Cramer, W., et al. (2001), Global response of terrestrial ecosystem structure and function to $\mathrm{CO}_{2}$ and climate change: Results from six dynamic global vegetation models, Global Change Biol., 7, 357-373, doi:10.1046/j.1365-2486.2001.00383.x.

Curtis, P. S., and X. Wang (1998), A meta-analysis of elevated $\mathrm{CO}_{2}$ effects on woody plant mass, form, and physiology, Oecologia, 113(3), 299-313, doi:10.1007/s004420050381.

Food and Agriculture Organization of the United Nations (1991), The digitalized soil map of the world (release 1.0), vol. 67/1, Food and Agric. Organ. of the U. N., Rome.

Hutyra, L. R., J. W. Munger, C. A. Nobre, S. R. Saleska, S. A. Vieira, and S. C. Wofsy (2005), Climate variability and vegetation vulnerability in Amazônia, Geophys. Res. Lett., 32, L24712, doi:10.1029/ 2005GL024981. 
Kriegler, E., J. W. Hall, H. Held, R. Dawson, and H. J. Schellnhuber (2009), Imprecise probability assessment of tipping points in the climate system, Proc. Natl. Acad. Sci. U. S. A., 106, 5041, doi:10.1073/ pnas.0809117106.

Lapola, D. M., M. D. Oyama, and C. A. Nobre (2009), Exploring the range of climate-biome projections for tropical South America: The role of $\mathrm{CO}_{2}$ fertilization and seasonality, Global Biogeochem. Cycles, 23, GB3003, doi:10.1029/2008GB003357.

Lenton, T. M., H. Held, E. Kriegler, J. W. Hall, W. Lucht, S. Rahmstorf, and H. S. Schellnhuber (2008), Tipping elements in the Earth's climate system, Proc. Natl. Acad. Sci. U. S. A., 105, 1786-1793, doi:10.1073/ pnas.0705414105.

Li, W., R. Fu, and R. E. Dickinson (2006), Rainfall and its seasonality over the Amazon in the 21 st century as assessed by the coupled models for the IPCC AR4, J. Geophys. Res., 111, D02111, doi:10.1029/2005JD006355.

Malhi, Y., and J. Wright (2004), Spatial patterns and recent trends in the climate of tropical rainforest regions, Philos. Trans. R. Soc. London, Ser. B, 359, 311-329, doi:10.1098/rstb.2003.1433.

Malhi, Y., J. T. Roberts, R. A. Betts, T. J. Killeen, W. Li, and C. A. Nobre (2008), Climate change, deforestation and the fate of the Amazon, Science, 319, 169-172, doi:10.1126/science.1146961.

Malhi, Y., L. E. O. Aragao, D. Galbraith, C. Huntingford, R. Fisher, P. Zelazowski, S. Sitch, C. Mcsweeney, and P. Meir (2009), Exploring the likelihood and mechanism of a climate-change-induced dieback of the Amazon rainforest, Proc. Natl. Acad. Sci. U. S. A., 106, 20,610-20,615, doi:10.1073/pnas.0804619106.

Marengo, J. A. (2009), Future change of climate in South America in the late 21 st century: The CREAS project, Atmos. Sci. Sect. AGU Newsl., $3(2), 5$.

Marengo, J. A., and T. Ambrizzi (2006), Use of regional climate models in impacts assessments and adaptations studies from continental to regional and local scales: The CREAS (Regional Climate Change Scenarios for South America) initiative in South America, in Proceedings of 8 ICSHMO, pp. 291-296, Foz do Iguaçu, Brazil.

Marengo, J. A., W. R. Soares, M. Nicolini, and C. Saulo (2004), Climatology of low-level jet east of the Andes as derived from the NCEPNCAR reanalysis: Characteristics and temporal variability, J. Clim., 17, 2261-2280, doi:10.1175/1520-0442(2004)017<2261:COTLJE>2.0. $\mathrm{CO} ; 2$.

Monserud, R. A., and R. Leemans (1992), Comparing global vegetation maps with the Kappa statistic, Ecol. Modell., 62, 275-293, doi:10.1016/ 0304-3800(92)90003-W.

Nepstad, D. C., C. M. Stickler, B. Soares-Filho, and F. Merry (2008), Interactions among Amazon land use, forests and climate: Prospects for a near-term forest tipping point, Philos. Trans. R. Soc. B, 363, 1737-1746, doi:10.1098/rstb.2007.0036.

Nobre, C. A., and L. S. Borma (2009), Tipping points for the Amazon forest, Curr. Opin. Environ. Sustainability, 1, 28-36, doi:10.1016/j.cosust. 2009.07.003.

Nobre, C. A., P. J. Sellers, and J. Shukla (1991), Amazonian deforestation and regional climate change, J. Clim., 4, 957-988, doi:10.1175/15200442(1991)004<0957:ADARCC $>2.0 . C O ; 2$.

Norby, R. J., et al. (2005), Forest response to elevated $\mathrm{CO}_{2}$ is conserved across a broad range of productivity, Proc. Natl. Acad. Sci. U. S. A., 102(50), 18,052-18,056, doi:10.1073/pnas.0509478102.
Oyama, M. D., and C. A. Nobre (2003), A new climate-vegetation equilibrium state for tropical South America, Geophys. Res. Lett., 30(23), 2199, doi:10.1029/2003GL018600.

Prentice, I. C., G. D. Farquhar, M. J. R. Fasham, M. L. Goulden, M. Heimann, V. J. Jaramillo, H. S. Kheshgi, C. Le Quéré, R. J. Scholes, and D. W. R. Wallace (2001), The carbon cycle and atmospheric carbon dioxide, in Climate Change 2001: The Scientific Basis. Contribution of Working Group I to the Third Assessment Report of the Intergovernmental Panel on Climate Change, edited by J. T. Houghton et al., pp. 183-238, Cambridge Univ. Press, Cambridge, U. K.

Raschke, E., S. Bakan, and S. Kinne (2006), An assessment of radiation budget data provided by the ISCCP and GEWEX-SRB, Geophys. Res. Lett., 33, L07812, doi:10.1029/2005GL025503.

Salazar, L. F. (2009), Consequências das mudanças climáticas no distribuição dos biomas na América do Sul, com ênfase na Amazônia e Nordeste, Ph.D. thesis, Cent. for Weather Forecast. and Clim. Stud., Natl. Inst. for Space Res., São José dos Campos, Brasil. (Available at http://urlib.net/ sid.inpe.br/mtc-m18@80/2009/05.29.14.11)

Salazar, L. F., C. A. Nobre, and M. D. Oyama (2007), Climate change consequences on the biome distribution in tropical South America, Geophys. Res. Lett., 34, L09708, doi:10.1029/2007GL029695.

Sampaio, G., C. A. Nobre, M. H. Costa, P. Satyamurty, B. S. Soares-Filho, and M. Cardoso (2007), Regional climate change over eastern Amazonia caused by pasture and soybean cropland expansion, Geophys. Res. Lett., 34, L17709, doi:10.1029/2007GL030612.

Scholze, M., W. Knorr, N. W. Arnell, and I. C. Prentice (2006), A climatechange risk analysis for world ecosystems, Proc. Natl. Acad. Sci. U. S. A. 103(35), 13,116-13,120, doi:10.1073/pnas.0601816103.

Sitch, S., et al. (2008), Evaluation of the terrestrial carbon cycle, future plant geography and climate-carbon feedbacks using 5 Dynamic Global Vegetation Models (DGVMs), Global Change Biol., 14(9), 2015-2039, doi:10.1111/j.1365-2486.2008.01626.x.

Turner, D. P., et al. (2006), Evaluation of MODIS NPP and GPP products across multiple biomes, Remote Sens. Environ., 102, 282-292, doi:10.1016/j.rse.2006.02.017.

Vera, C., G. Silvestri, B. Liebmann, and P. González (2006), Climate change scenarios for seasonal precipitation in South America from IPCC-AR4 models, Geophys. Res. Lett., 33, L13707, doi:10.1029/ 2006 GL025759.

Victoria, R. L., L. A. Martinelli, J. M. Moraes, M. V. Ballester, A. V. Krusche, G. Pellegrino, R. M. B. Almeida, and J. E. Richey (1998), Surface air temperature variations in the Amazon region and its borders during this century, J. Clim., 11, 1105-1110, doi:10.1175/1520-0442 (1998)011<1105:SATVIT>2.0.CO;2.

C. A. Nobre, Center for Earth System Science, National Institute of Space Research, Av. dos Astronautas 1758, Caixa Postal 515 1220, Cachoeira Paulista, SP 12630-000, Brazil.

L. F. Salazar, Escuela de Ingeniería Civil, Universidad Industrial de Santander, Calle 27 x Carrera 9, Ciudad Universitaria, Bucaramanga, Colombia. (fsalazar@uis.edu.co) 